\title{
Pengetahuan Dan Sikap Ibu Hamil Tentang Pencegahan Penularan Penyakit Hepatitis B Pada Janin Di Puskesmas Ciaparay Kabupaten Bandung Tahun 2019
}

\author{
Yanyan Mulyani*, Vaurel Nurul Salsabil \\ Fakultas Ilmu Kesehatan Universitas Bhakti Kencana \\ Corresponding author: Yanyan Mulyani (yanyan.mulyani@bku.ac.id) \\ Received: Mei, 20 2020; Accepted: June, 28 2020; Published: September, 12020
}

\begin{abstract}
ABSTRAK
Hepatitis B merupakan penyakit menular serius dan umumnya menginfeksi hati yang disebabkan oleh virus hepatitis B (HBV) yang menyebabkan Salah satu cara agar tidak terjadi penularan adalah dengan melakukan pencegahan yaitu dengan memberikan imunisasi hepatitis B pada bayi baru lahir.

Tujuan dari penelitian ini adalah untuk mengetahui bagaimana pengetahuan dan sikap ibu hamil tentang pencegahan penyakit hepatitis B pada janin di Puskesmas Ciparay Kabupaten Bandung. Jenis penelitian yang digunakan dalam penelitian ini adalah deskriptif yaitu penelitian yang berusaha mendeskripsikan suatu gejala, peristiwa, kejadian yang terjadi saat ini di masyarakat.

Penelitian ini menggunakan sampel ibu hamil dengan jumlah 64 responden dengan teknik Accidental Sampling. Dan data yang didapatkan dari responden dilakukan dengan membagikan kuisioner. Hasil dari penelitian ini adalah sebanyak 34 responden (53.1\%) memiliki pengetahuan kurang. 19 responden (29.7\%) memiliki pengetahuan cukup, dan 11 responden $(17.2 \%)$ memiliki pengetahuan baik. Sedangkan 28 responden $(43.8 \%)$ memiliki sikap negative, dan 36 responden (56.2\%) memiliki sikap positif.

Simpulan dari penelitian ini adalah dari 64 responden lebih dari setengahnya memiliki pengetahuan kurang dan sikap yang positif. Sehingga dapat disarankan hasil penelitian ini dapat menjadi informasi bagi mahasiswa, ibu hamil, atau siapapun yang membutuhkan informasi mengenai pencegahan penularan penyakit Hepatitis B pada Janin.
\end{abstract}

Kata Kunci: Pengetahuan, Sikap, Ibu hamil, Hepatitis B

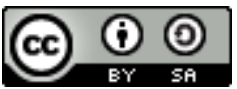

This is an open-acces article distributed under the terms of the Creative Commons Attribution-ShareAlike 4.0 International License.

\section{PENDAHULUAN}

Sustainable Development Goals atau SDGs merupakan agenda berkelanjutan pembangunan yang telah disepakati sebagai cara untuk pembangunan global. Mulai tahun 2015, tujuan pembangunan berkelanjutan atau SDGs diberlakukan sejak tahun 2015-2030. Salah satu tujuan dari SDGs itu sendiri adalah kesehatan yang baik dan kesejahteraan hidup untuk seluruh masyarakat disegala umur. ${ }^{(1)}$ 
Berdasarkan Survei Demografi dan Kesehatan Indonesia (SDKI) tahun 2017, menunjukan angka kematian bayi di Indonesia masih tinggi sebesar 32 per $1000 \mathrm{KH}$. Di kutip dari halaman resmi kementrian kesehatan bahwa jumlah kasus kematian bayi sebanyak 33.278 kasus pada tahun 2015. Sedangkan pada tahun 2016 turun menjadi 32.0007 kasus. Sementara pada tahun 2017 sampai pertengahan tercatat 10.294 kasus kematian bayi. (2)

Di Indonesia penyebab kematian bayi yang paling tinggi adalah Asfiksia, Infeksi dan berat badan bayi rendah. Dari keterangan diatas bahwa infeksi menjadi penyebab kedua setelah Asfiksia dan salah satu infeksi penyebab kematian bayi adalah infeksi Hepatitis B yang dapat ditularkan dari ibu yang mengidap penyakit hepatitis B ke bayi yang dilahirknnya. ${ }^{(2)}$

Hepatitis B merupakan penyakit menular serius dan umumnya menginfeksi hati disebabkan oleh virus Hepatitis B (HBV) yang dapat menyebabkan penyakit akut maupun kronis. Kebanyakan orang tidak menyadari telah terinfeksi. Lebih dari 686.000 orang meninggal setiap tahun akibat komplikasi dari Hepatitis B, termasuk sirosis dan kanker hati. ${ }^{(3)}$

HBV telah menjadi penyakit endemis di berbagai negara di dunia. Indonesia merupakan negara dengan endemisitas Hepatitis B tinggi, tercatat Indonesia merupakan negara terbesar kedua di South East Asian Region (SEAR) setelah Myanmar. Didapatkan dari data Riset Kesehatan Dasar Indonesia tahun 2013, dari studi dan uji saring darah donor PMI, diperkirakan di antara 100 orang di Indonesia, maka 10 di antaranya telah terinfeksi hepatitis B atau C. (3)

Dari data tersebut, saat ini diperkirakan terdapat 28 juta penduduk Indonesia yang terinfeksi hepatitis B dan C, 14 juta di antaranya berpotensi untuk menjadi kronis, dan dari yang kronis tersebut 1,4 juta orang berpotensi untuk menderita kanker hepatoseluler. Besarnya masalah tersebut berdampak terhadap masalah kesehatan masyarakat, produktifitas, umur, harapan hidup, dan dampak negara ekonomi lainnya. ${ }^{(4)}$

Menurut data Depkes RI pada tahun 2013, bahwa di wilayah jawa barat ibu hamil yang terdeteksi HbsAg reaktif adalah 1,4\%. ${ }^{(5)}$ Sementara itu di kabupaten Bandung tercatat bahwa ibu hamil dengan Hepatitis B berjumlah 4,7\%.(6) Sedangkan dipuskesmas ciparay tercatat sekitar $8,1 \%$ ibu hamil yang terpapar hepatitis B. ${ }^{(7)}$

Wanita hamil adalah kelompok yang rentan terkena virus Hepatitis B. Perhimpunan Peneliti Hati Indonesia (PPHI), mengatakan bahwa Hepatitis B pada anak karena virus masuk melalui jalan lahir ibu. Pada umumnya bayi dalam kandungan memang tidak terpengaruh oleh virus hepatitis B milik ibunya selama kehamilan. Namun, ada beberapa peningkatan resiko tertentu saat persalinan seperti, bayi lahir premature, BBLR, atau kelainan anatomi dan fungsi tubuh bayi (terutama pada infeksi hepatitis B kronis). ${ }^{(8)}$

Bayi mungkin terinfeksi hepatitis B saat lahir jika ibunya positif memiliki virusnya. Infeksi hepatitis B dapat sembuh total dalam beberapa minggu tanpa pengobatan. Ibu hamil yang sudah terbebas dari virus hepatitis B akan menjadi kebal terhadapnya. Mereka tidak bisa terkena virus lagi. Kehamilan itu sendiri tidak akan mempercepat proses penyakit atau memperburuk keadaannya, walaupun jika hati sudah terbebani dan terluka dengan sirosis, ini dapat meningkatkan risiko ibu hamil mengalami perlemakan hati. ${ }^{(8)}$

Perlemakan hati selama kehamilan yang akut mungkin terkait kekurangan enzim yang biasanya di produksi oleh hati yang memungkinkan wanita hamil untuk memetabolisme asam lemak. Kondisi ini dapat dengan cepat menjadi parah, dan juga bisa mempengaruhi anak yang belum lahir (lahir dengan kekurangan enzim). ${ }^{(8)}$

Ibu hamil yang mengalami hepatitis B lebih rentan mengalami ketuban pecah dini, diabetes gestasional, atau perdarahan pada akhir kehamilan dan juga meningkatkan komplikasi persalinan seperti plasenta abrupsio dan kematian bayi saat lahir. Pemutusan rantai penularan sangat penting dilakukan, termasuk salah satunya adalah dari ibu pengidap hepatitis B ke janinnya. ${ }^{(9)}$ 
Ibu hamil yang terinfeksi dapat infeksi HBV menularkan virus ke bayi mereka selama kehamilan atau persalinan (3,4\%). Hampir 90\% dari bayi-bayi ini akan terinfeksi HBV kronis pada saat lahir jika tidak ada pencegahan. Semua wanita hamil harus diuji HBV untuk mencegah infeksi. Meskipun sebagian besar wanita tidak memiliki komplikasi kehamilan sebagai akibat dari infeksi HBV, mereka masih memerlukan pemeriksaan HBV karena efek jangka panjang pada bayi yang akan dilahirkannya. ${ }^{(9)}$

Puskesmas ciparay merupakan salah satu puskesmas yang berada di kabupaten Bandung, yang dapat memberikan pelayanan kesehatan diantaranya adalah pemeriksaan pada ibu hamil, menurut data dari dinas kabupaten Bandung puskesmas ciparay mempunyai ibu hamil yang terpapar hepatitis B tertinggi.

Kemungkinan peningkatan penyakit Hepatitis B di wilayah puskesmas Ciparay disebabkan oleh kurangnya pengetahuan masyarakat mengenai penyakit Hepatitis B sehingga dapat mempengaruhi sikap dan perilaku dalam upaya pencegahan penularan penyakit Hepatitis $\mathrm{B}$ ini. Kurangnya rasa ingin tahu masyarakat mempengaruhi dalam sikap dan perilaku yang akan dilakukan. Kurangnya fasilitas yang dapat mendukung dalam pemberian informasi tentang penyakit Hepatitis B juga dapat menjadi salah satu alasan kurangnya pengetahuan masyarakat.

\section{BAHAN DAN METODE}

Jenis penelitian yang digunakan dalam penelitian ini adalah deskriptif yaitu penelitian yang berusaha mendeskripsikan suatu gejala, peristiwa, kejadian yang terjadi saat ini di masyarakat. (19) Menurut Ari Kunto penelitian deskriptif adalah penelitian yang dimaksudkan untuk mengumpulkan informasi mengenai status gejala yang ada, dan keadaan gejala menurut apa adanya pada saat penelitian dilakukan. Di dalam penelitian ini akan mendeskripsikan bagaimana gambaran pengetahuan ibu hamil tentang pencegahan penularan penyakit Hepatitis B pada janin.

Populasi kumpulan individu akan diukur atau diamati ciri-cirinya. Populasi adalah keseluruhan dari objek penelitian. ${ }^{(19)}$ Populasi dari penelitian ini adalah seluruh ibu hamil pada bulan maret tahun 2019 yang ada di wilayah puskesmas Ciparay yang berjumlah 76 orang. Untuk pengambilan sampel digunakan rumus slovin $0.05 \%$ dan didapat hasil 64 responden

\section{HASIL DAN PEMBAHASAN}

Distribusi Frekuensi Responden Gambaran Pengetahuan Ibu Hamil tentang Pencegahan Penyakit Hepatitis B pada janin di Puskesmas Ciparay Kabupaten Bandung

\begin{tabular}{ccc}
\hline Pengetahuan & Jumlah Responden & Presentase \\
\hline Baik & 11 & $7.2 \%$ \\
Cukup & 19 & $29.7 \%$ \\
Kurang & 34 & $53.1 \%$ \\
\hline Total & 64 & $100 \%$ \\
\hline
\end{tabular}

Sumber : Data Primer (2019)

Berdasarkan hasil dari penelitian di Puskesmas Ciparay kabupaten Bandung didapatkan tabel diatas diperoleh data bahwa pengetahuan ibu hamil tentang pencegahan penyakit hepatitis B pada janin sebagian besar berpengetahuan kurang sebanyak 34 responden $(53.1 \%)$.

Distribusi Frekuensi Responden Gambaran Sikap Ibu Hamil tentang pencegahan penyakit hepatitis B pada janin di Puskesmas Ciparay Kabupaten Bandung 


\begin{tabular}{lcc}
\hline Sikap & Jumlah & Persentase \% \\
\hline Positif & 36 & $56.2 \%$ \\
Negatif & 28 & $43.8 \%$ \\
\hline Total & 64 & $100 \%$ \\
\hline
\end{tabular}

Sumber : Data Primer (2019)

Berdasarkan hasil dari penelitian yang dilakukan di Puskesmas Ciparay Kabupaten Bandung didapatkan diatas diperoleh data bahwa sikap ibu hamil tentang pencegahan penyakit hepatitis B pada janin sebagian besar memiliki sikap positif yang berjumlah 36 responden $(56.2$ $\%)$.

Hasil analisa pada tabel 4.1. diperoleh data bahwa pengetahuan ibu hamil tentang pencegahan penyakit hepatitis B pada janin sebagian besar berpengetahuan kurang sebanyak 34 responden $(53.1 \%)$.

Pengetahuan adalah hasil penginderaan manusia, atau hasil tahu seseorang terhadap suatu objek dari indra yang dimilikinya. Pengetahuan (knowledge) adalah hasil tahu dari manusia, yang sekedar menjawab pernyataan 'what'. Pengetahuan merupakan hasil dari tahu, dan ini terjadi setelah orang melakukan penginderaan terhadap suatu objek tertentu. Beberapa factor yang mempengaruhi pengetahuan yang pertama adalah pendidikan, media massa, ekonomi, hubungan social daan pengalaman. Tingkat pendidikan seseorang akan mempengaruhi pemberian respon yang datang dari luar. Orang yang berpendidikan akan berfikir seberapa banyak keuntungan yang akan mungkin mereka peroleh dari gagasan tersebut.

Penyakit Hepatitis B merupakan penyakit menular serius dan umumnya menginfeksi hati disebabkan oleh virus Hepatitis B (HBV) yang dapat menyebabkan penyakit akut maupun kronis. ${ }^{(3)}$

Cara penularan dari penyakit Hepatitis B melalui 2 cara yaitu secara Horizontal dan Vertikal. Secara horizontal yaitu melalui cairan tubuh seperti transfusi darah, melakukan hubungan seksual, dan penggunaan jarum suntik secara bersamaan. Sedangkan secara vertical melalui ibu ke bayinya. ${ }^{(16)}$

Berdasarkan hasil penelitian yang dilakukan di Puskesmas Ciparay Kabupaten Bandung mengenai pengetahuan pencegahan penularan penyakit Hepatitis B pada janin sebagian besar memiliki pengetahuan yang kurang yaitu sebanyak 34 responden (52.3\%). Ini dikarenakan lebih dari setengahnya responden memiliki pendidikan yang rendah $(50.8 \%)$, sehingga dapat mempengaruhi kadar pengetahuan seseorang. Pendidikan dapat menjadi latarbelakang atau penyebab utama pengetahuan seseorang. Dan menurut penulis bahwa semakin tinggi tingkat pendidikan seseorang maka semakin terbuka orang tersebut untuk menerima informasi yang disampaikan oleh tenaga kesehatan. Penyebab pengetahuan responden yang kurang dikarenakan tingkat pendidikan yang rendah serta responden tidak memahami pengetahuan yang pernah didapatkan, baik itu pengetahuan yang didapat dari keluarga, masyarakat, tenaga kesehatan, ataupun dari pengalaman yang responden dapatkan. Selain itu, masyarakat yang memiliki tingkat pendidikan rendah dapat juga tidak mengerti dengan informasi yang disampaikan. Dengan begitu responden tidak dapat mengingat ataupun menjelaskan kembali mengenai pengatahuan tentang Hepatitis B.

Berdasarkan hasil penelitian yang dilakukan di Puskesmas Ciparay Kabupaten bandung responden kurang memahami mengenai cara penularan penyakit hepatitis $\mathrm{B}$ dan hanya 30 responden (46.8\%) yang dapat menjawab dengan benar.

Berdasarkan table 4.2. diperoleh data bahwa sikap ibu hamil tentang pencegahan penyakit hepatitis B pada janin sebagian besar dari responden $(56.2 \%)$ memiliki sikap positif. 
Berdasarkan teori bahwa Sikap dalam arti yang sempit adalah pandangan atau kecenderungan mental. Sikap (attitude) adalah suatu kecenderungan untuk mereaksi suatu hal, orang atau benda dengan suka, tidak suka atau acuh tak acuh. Dengan demikian, pada prinsipnya sikap itu dapat kita anggap suatu kecenderungan untuk bertindak dengan cara tertentu. ${ }^{(21)}$

Hasil dari penelitian menunjukan bahwa sebagian besar responden memiliki sikap positif dikarenakan beberapa factor, salah satunya adalah pengetahuan sehingga dapat mempengaruhi dalam pengambilan sikap seseorang. Cukupnya sumber informasi, dan adanya keinginan untuk mencari tahu sehingga responden dapat bersikap positif. Menurut penulis jika tingkat pendidikan responden tinggi dapat memudahkan responden untuk menerima berbagai informasi dan memiliki fikiran terbuka. Pengetahuan yang baik dapat mencerminkan sikap yang positif. Akan tetapi, meskipun sebagian besar responden memiliki pengetahuan kurang, responden mendukung dengan cara bersikap positif.

Sedangkan hampir setengahnya dari responden memiliki sikap negatif karena pengetahuan dapat pula mempengaruhi dalam pengambilan sikap, serta memiliki informasi yang kurang. Maka dari itu responden dapat bersikap negatif.

\section{KESIMPULAN}

Berdasarkan hasil penelitian yang telah dilakukan pada 65 responden di puskesmas Ciparay Kabupaten

Bandung bahwa lebih dari setengahnya memiliki pengetahuan yang kurang, dan lebih dari setengah responden memiliki sikap negative. Diharapkan dengan adanya hasil penelitian ini pihak puskeskesmas Ciparay lebih giat lagi untuk memberikan penyuluhan mengenai penyakit Hepatitis B.

\section{UCAPAN TERIMAKASIH}

Ucapan terimakasih kepada Pemerintah Indonesia Khususnya Dinas Kesehatan Kabupaten Bandung yang telah memberi kesempatan kepada penulis untuk tugas belajar, kepada keluarga, orangtua yang senantiasa memberi dukungan serta pembimbing yang telah sabar membimbing penulis dalam penyusunan laporan ini. Terimakasih juga pada pihak Puskesmas Ciparay yang telah mengizinkan penulis untuk dapat melakukan penelitian. Serta ibu hamil sebagai responden yang telah berpartisipasi dalam kegiatan penelitian ini.

\section{DAFTAR PUSTAKA}

Nugroho. Tujuan SDGs. 2017.

RI K. Capaian Kinerja Kemenkes RI Tahun 2015-20172017.

Kusnanto NAH. Prevalensi infeksi virus Hepatitis B pada bayi dan anak yang dilahirkan ibu dengan HBsAg positif. 2017:516.

RISKESDAS. RISKESDAS Kementrian Kesehatan. 2013.

RI D. 2018. 6. Istantina A. Hepatitis Pada ibu Hamil. 2018.

Dinkes. 2018.

Quamila. Hepatitis saat Hamil, Dampak bagi Ibu dan Bayi. 2017.

Syifa Mustika DH. Prevalensi Infeksi Hepatitis B pada Ibu Hamil di Malang. 2018.

Rahmawati F. Hubungan pengetahuan ibu dengan Status Gizi Balita. 2016:10.

Arifin R. Hubungan tingkat pengetahuan ibu tentang kebutuhan Gizi pada ibu hamil 2016:11. Huba NR. teori Sikap. 2014.

Cahya Juwitaningsih DR, Elda Desiana S., Erliyana Dwi S, Hidayah Nur F, I Gusti Ayu Ary A. Asuhan Kehamilan 2013.

liswidyawati rahayu SS. Waspada Wabah Penyakit Bandung: PT Nuansa Bandung; 2010. 
Irianto K. Memahami Berbagai Penyakit Bandung: Alfabeta; 2015. 16. Prof. Dr. dr. IGP Surya SK, dr. RyanSaktika Mulyana, M. Biomed, Sp.OG, dr. Endang Sri Widiyanti, m. Biomed, Sp.OG. Kehamilan Dengan Hepatitis B. Jakarta: CV Sagung Seto; 2016.

Wahyudi H. Hepatitis. 2017.

dr M. Marianti d, editor2017. Available from: https://www.alodokter.com.

Notoatmodjo S. Metodologi Penelitian Kesehatan Jakarta: Rineka Cipta; 2010.

Prasko SST, M.H. Pengertian dan Jenis Kuesioner. 2017.

dr. Suparyanto MK. Sekilas tentang Sikap. 2013.

University BN. Uji Validitas dan Reliabilitas. 2014. 23. Nandhie. Asuhan Kebidanan Pada ibu

Hamil dengan Hepatitis B. 2012. 